
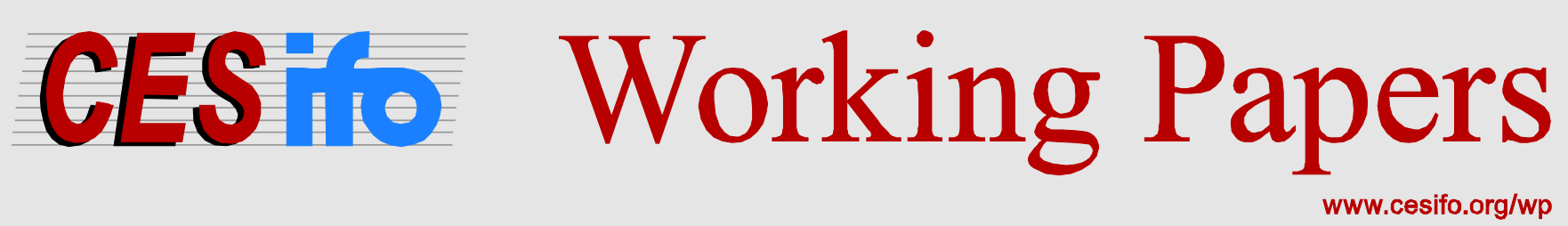

\title{
The Impact of Economic Globalization on the Shadow Economy in Egypt
}

\author{
Mohammad Reza Farzanegan \\ Mai Hassan
}

\section{CESIFO WORKING PAPER NO. 6424 \\ CATEGORY 1: PuBlic FinANCE \\ MARCH 2017}

An electronic version of the paper may be downloaded

- from the SSRN website:

- from the RePEc website:

- from the CESifo website:

WwW.SSRN.com

Www.RePEc.org

www.CESifo-group.org/wp

\section{CESifo}




\title{
The Impact of Economic Globalization on the Shadow Economy in Egypt
}

\begin{abstract}
This study examines the economic globalization and the shadow economy nexus in Egypt. Using time series data from 1976 to 2013, the impulse response analysis shows that the response of the shadow economy in Egypt to positive shocks in economic globalization is negative and statistically significant for the first three years following the shock. This finding is obtained by controlling for several intermediary channels in globalization-shadow economy nexus such as education, government spending, industrial production, and labor force participation. Our results show the importance of promoting economic globalization by reducing the costs of doing business and trade in dealing with sizable shadow economy in Egypt.
\end{abstract}

JEL-Codes: C530, F150, F400, O530.

Keywords: shadow economy, globalization, VAR model, impulse responses, Egypt.

Mohammad Reza Farzanegan Philipps-University of Marburg

Deutschhausstr. 12

Germany - 35032 Marburg

farzanegan@staff.uni-marburg.de
Mai Hassan

Philipps-University of Marburg

Deutschhausstr. 12

Germany - 35032 Marburg

mai.hassan@staff.uni-marburg.de 


\section{Introduction}

We aim to investigate the impact of economic globalization ${ }^{1}$ shocks on the development of the shadow economy ${ }^{2}$ in Egypt. According to the estimations of Hassan and Schneider (2016), the relative share of Egyptian shadow economy in GDP was significant during 1970s and 1980s reaching more than $30 \%$ of GDP. Since 1990 s, we are observing a continuous decline in the size of shadow economy in Egypt, reaching approximately $20 \%$ of GDP in 2013. Figure 1 shows the development of the shadow economy in Egypt since 1976. Based on the Egyptian Labor Survey (ELS), 60\% of the informal labor are women, the majority are single and young (15-9 years old). Also, $68 \%$ are illiterate compared to $26 \%$ who have above intermediate education. The share of the informal workers are most prominent in textile industry, furniture, paper and wood production, metal and leather production (Selwaness and Zaki, 2013). Although the development of the shadow economy shows a decreasing trend, its relative size is still significant. The shadow economy bears a huge burden on the formal economy hindering the country's development and growth.

Figure 1. Shadow economy (\% of GDP) in Egypt (1976-2013)

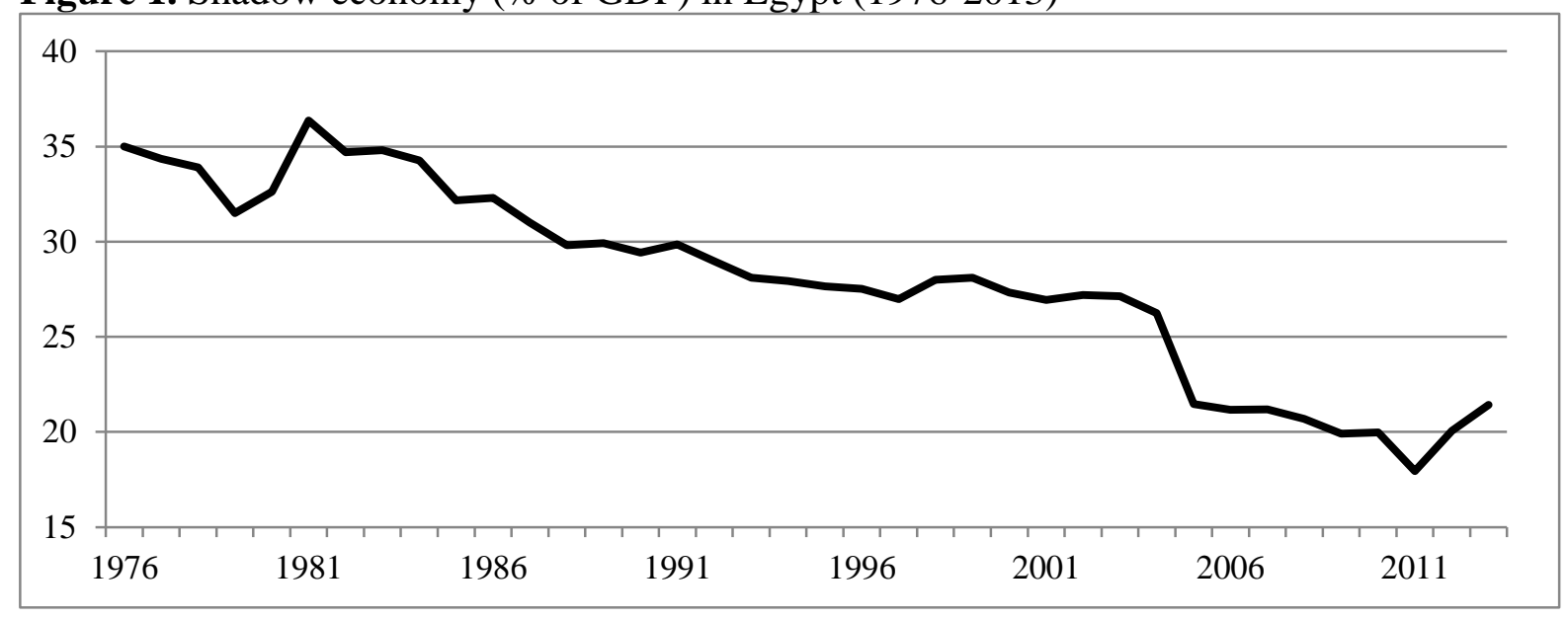

Source: Hassan and Schneider (2016)

\footnotetext{
${ }^{1} \mathrm{We}$ focus on a particular aspect of globalization which is economic globalization. Economic globalization involves the long-distance flow of goods, services, capital and information resulting from intermarket exchanges (Koehane and Nye, 2000). We follow Dreher (2006) in measuring the economic globalization.

${ }^{2}$ In this study, the shadow economy involves all the market-based activities that should have been included in the overall income of a country (Schneider et al., 2010).
} 
There are different factors which are playing a role in historical development of the shadow economy in Egypt. One of them is the economic globalization of Egypt. Figure 2 shows the economic globalization trend in Egypt. The increasing trend of integration of Egyptian economy in global and regional markets has been facilitated through various policy reforms and trade agreements such as the EGYPT-EU partnership ${ }^{3}$, or the Greater Arab Free Trade Agreement (GAFTA) $)^{4}$

Figure 2. The Economic Globalization in Egypt (1970-2013)

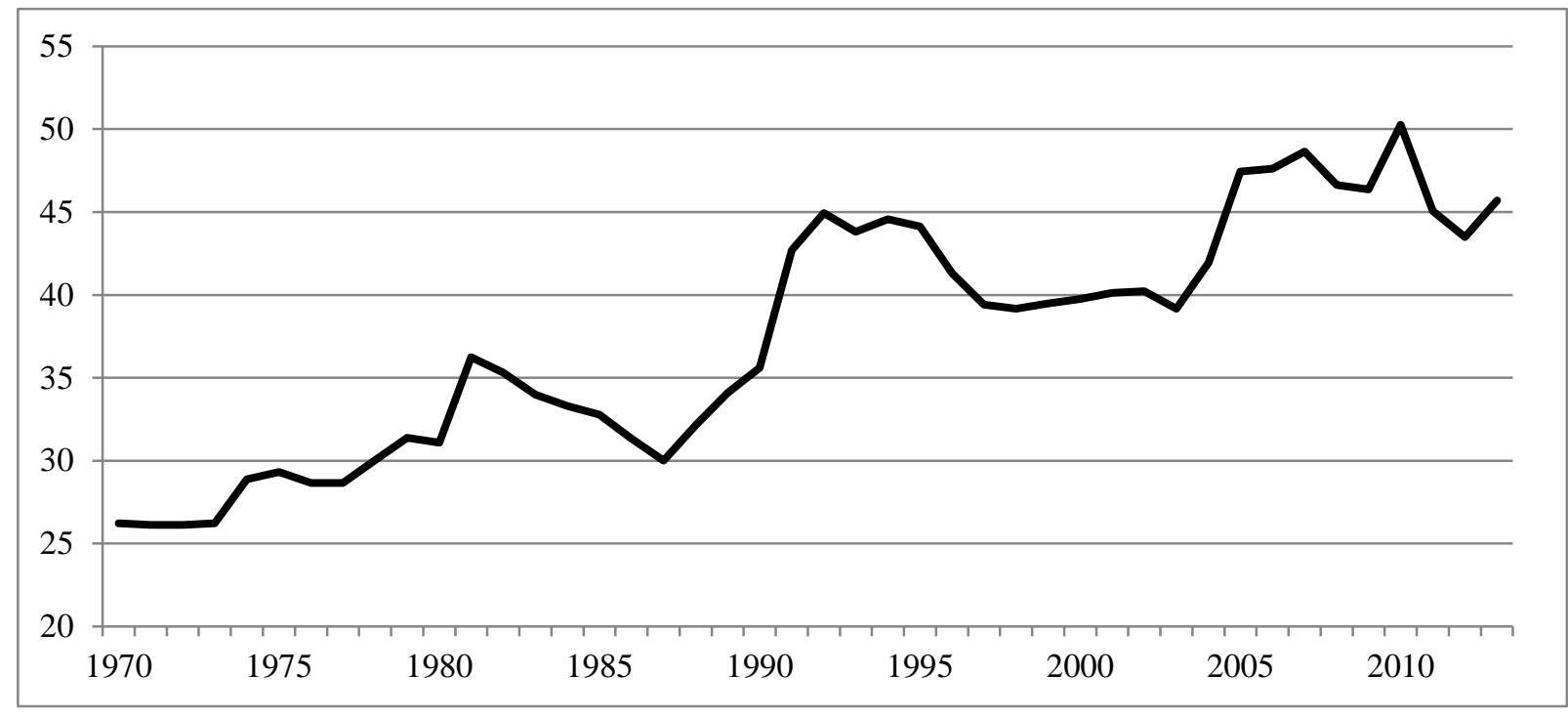

Source: Dreher (2006) and http://globalization.kof.ethz.ch/

Globalization may reduce the proliferation of the shadow economy through different channels including increasing productivity and expanding the formal economy, reducing labor market rigidities, improving institutional quality, increasing wages, and reducing tariffs and trade restrictions (Geronazzo, 2016; Melitz, 2003; Aleman-Castilla, 2006; Dreher et al. 2009). However, there are also arguments in the literature which undermine the constructive contribution of globalization in dealing with the shadow economy. Studies such as Carr and Chen (2002), Goldberg and Pavcnik (2003) and Bacchetta et al. (2009) suggest that the economic globalization may even increase the size of the shadow economy through intensifying

\footnotetext{
${ }^{3}$ https://goo.gl/4o3XCV (Access 24.03.2017)

${ }^{4}$ http://www.economy.gov.lb/?/subSubcatInfo/2/91 (Access 24.03.2017)
} 
competition, increasing costs, and under-privileging domestic low skilled labor to global work force.

Our study aims to shed more light on the impact of economic globalization on development of the shadow economy, using time series data from 1976 to 2013 in Egypt. We use an innovative approach which traces the response of the shadow economy of Egypt to a positive shock in economic globalization of Egypt over the years after shock. Our estimated impulse responses based on vector autoregressive model shows a negative response of the shadow economy to globalization positive shock which is also statistically significant in the first 3 years after shock. The following paper is organized as follows. Section 2 presents a review of related literature on the relationship between globalization and shadow economy. In Section 3, we explain the globalization efforts in Egypt. Section 4 focuses on the data and methodology. We present and discuss the results in Section 5. Finally, Section 6 concludes.

\section{Globalization and the shadow economy nexus}

The shadow economy is most prominent in developing countries relative to developed countries. The average size of the shadow economy in developing countries reached $32 \%$ of GDP compared to 18\% of GDP in high income OECD countries from 1999 to 2007 (Schneider et al. 2010).

It is important to tackle the subject of informality in our modern globalized economies because informal jobs are associated with lower wages, poor working conditions, and no social security benefits such as public health insurance, unemployment security or pensions. In addition, a relatively large size of the shadow economy has also different negative externalities on the overall economy. The shadow economy hinders the development of the overall economy as it absorbs capital resources and labor from the formal economy, limits public resources that could be used efficiently, limits the effectiveness of the policies as it creates distortions in the official statistics, creates unfair competition against formal firms that abide by the laws and adds 
minimum value to the formal economy due to the low productivity of the informal firms (La Porta and Schleifer, 2014; Gerxhani, 2004, Schneider and Enste, 2000). Additionally, the existence of the shadow economy increases pollution as the informal firms do not have access to financial means to employ green technology (Biswas et al., 2012). Most importantly, the existence of the shadow economy influences the development of an economy as it hinders the country's integration to the global economy by preventing it from creating a large and diversified export market (Bacchetta et al., 2009).

How does the shadow economy react to globalization? There are two main streams regarding the impact of globalization on the shadow economy. The first stream affirms that globalization has positive impacts in terms of reducing informality, while the second stream highlights its negative consequences.

On the one hand, globalization increases productivity through a better reallocation of production factors and resources in the formal economy. Thus, the formal economy expands opening up opportunities for more productive firms to enter the official economy, while less efficient and less productive firms (i.e. informal firms) either reallocate to join the official economy or they disappear (Melitz, 2003). The positive spillover effects of globalization is highly evident in developing countries. For instance, Utkulu and Özdemir (2004) as well as Herath (2010) and Chaudhry (2010) concluded that globalization has a positive impact on economic growth for the case of Turkey, Sri Lanka and Pakistan, respectively. As a result, more income and new job opportunities are created so it becomes less attractive for informal firms and individuals to participate in the shadow economy leading to a reduction in informality. Furthermore, globalization might lead to more deregulation of labor markets. Flexible labor markets attract domestic labor and foreign investors to work in the formal economy facilitating the process of globalization. Examples of labor market deregulation include flexible labor laws, reducing government intervention, lowering minimum wage or employment costs (Potrafke, 
2014). Globalization improves the labor conditions in the formal economy which in return reduces the informality through the channel of reducing labor market regulations ${ }^{5}$.

Also, globalization leads to an increase in wages. The formalization of informal firms and the addition of the more productive and efficient firms in the formal economy create more employment opportunities, leading to an increase in wages as the demand on formal labor increases. Therefore, the wage gap between formal and informal jobs widens, making it more attractive for informal labor to seek jobs with higher income and better benefits in the formal economy rather than in the shadow economy (Temkin and Veizaga, 2010; Geronazzo, 2016). By the same token, Aleman-Castilla (2006) argues that the positive spill-over effects of globalization such as the reduction of tariffs and trade restrictions ${ }^{6}$ makes it more profitable for firms to operate in the official economy and engage in international trade rather than to stay in the shadow economy. Given the status of informal firms as being unregistered in the formal economy, they cannot import nor export and cannot benefit from trade agreements. Globalization brings about trade openness which in return induces public officials to reduce governmental restrictions and to provide incentives for integration of domestic firms in international trade as well as attracting foreign investors (Schneider and Enste, 2000).

In addition, Acosta and Gasparini (2007) and Geronazzo, (2016) argue that firms can reduce costs and improve working conditions through the adoption of advanced technologies. Consequently, more informal firms join the formal economy to have better access to the advanced technologies and intermediaries brought by opening the economy to globalization. Therefore, informal firms find it more attractive to formalize their activities and exit the shadow economy.

\footnotetext{
${ }^{5}$ Various authors such as Buehn and Schneider (2008), Johnson et al. (1998), Schneider (2005) concluded that the regulatory burden increases informality.

${ }^{6}$ Higher tariffs and trade restrictions increases the incident of smuggling as a part of the shadow economy

(Buehn and Farzanegan, 2012)
} 
Moreover, globalization improves institutional quality and reduces corruption which in return reduces the growth of the size of the shadow economy (Dreher et al., 2009; Dong et al., 2012). The complementary relationship between low institutional quality, weak rule of law, corruption and the shadow economy is supported in the literature (Razmi et al. 2013; Buehn and Farzanegan, 2012; Schneider, 2010).

Finally, Kearney ${ }^{7}(2006: 80)$ concluded that there is a negative relationship between globalization index and informality. This means that the higher the level of globalization in a country, the smaller is the size of the shadow economy. Globalization does not give room for the informal firms operating in the shadow economy. Informal firms are small in size relative to formal firms, are less productive in terms of value-added per employee, and are highly inefficient producing low quality products.

On the other hand, globalization may not reduce informality especially in developing countries as their local low-skilled labor has been underprivileged when compared to the global work force who could easily move and integrate to international markets. Global firms take advantage of the large shadow economies and cheap unskilled labor in developing countries by pushing for more informal employment. Additionally, many small- and medium- sized companies, due to increased competition, are highly disadvantaged. Local small- and medium- sized companies might lose their local market niches to imported products and to international conglomerates which can capture markets quickly (Carr and Chen, 2002). An additional consequence of globalization is increased costs. Thus, local companies tend to replace employees with temporary workers on an informal basis or lay off employees who seek then employment in the shadow economy (Goldberg and Pavcnik, 2003). Globalization has made it challenging for formal local firms, particularly small- and medium- sized companies in developing countries,

\footnotetext{
${ }^{7}$ The A.T. Kearney Global Cities Index (GCI) ranks 125 cities according to 27 metrics across five dimensions, including business activity, human capital, information exchange, cultural experience, and political engagement.
} 
to integrate and survive in the globalized economy which has to some extent resulted in the proliferation of the shadow economy (Bacchetta et al., 2009). At the end, globalization might lead to negative consequences on the overall economy that might increase the spread of the shadow economy ${ }^{8}$.

The impact of globalization on the size of the shadow economy is still a controversial matter with different views. The response of the shadow economy to the economic globalization may differ from one country to another, depending on the institutions and socio-economic conditions. In this study, we examine this controversial nexus for the case of Egypt.

\section{Globalization and the shadow economy in Egypt}

Many developing countries, including Egypt, have been undertaking major policy reforms in order to liberalize the national economy and benefit from globalization. Throughout the years, policy makers in Egypt aimed to ease up the business environment in order to encourage individuals to participate in the formal economy to help in the globalization process. These business regulatory reforms ${ }^{9}$ included lowering of registration fees and reducing costs of startups, and reducing the minimum capital requirement to open up a new business. In addition, the reform focused on abolishing bar association fees and an automating tax registration system was initiated in 2009. Moreover, the process of opening up a new business in Egypt was improved by merging procedures at the one-stop shop by introducing a follow-up unit in charge of liaising with the tax and labor authority on behalf of the company. Additionally, policy makers in Egypt improved the integration of the domestic economy to the global economy by improving customs administration, upgrading port facilities at Alexandria and speeding up customs clearance and by introducing an electronic system for submitting export and import documents ${ }^{10}$.

\footnotetext{
${ }^{8}$ For further details, refer to Egharevba (2011), Pham (2011), Siggel (2010), Verick (2008)

${ }^{9}$ Doing business reforms published the World Bank record the major reforms conducted by a certain country; i.e. Egypt.

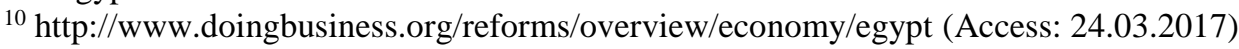


In addition to these reforms, Egypt engaged in different trading agreements such as the EGYPTEU partnership, EGYPT-EFTA partnership, Greater Arab Free Trade Agreement (GAFTA), EGYPT-TURKEY Free Trade Agreement, and the COMESA. The main objective of these trade agreements is to increase foreign investment, to liberalize trade by removing tariffs as well as trade restrictions and to provide immediate duty free access of Egyptian products into the global markets so as to achieve the ultimate goal of globalizing the domestic economy. Furthermore, policy makers have targeted the industrial sector in order to integrate the domestic economy with the global economies. Industrialization began in Egypt since the 1920s. In the 1920s, the dominating sector in Egypt was the agriculture sector to the extent that 3 quarter of the Egyptian exports were raw cotton. Therefore, the main industrial output was cotton spinning and weaving. During the 1930s, the private sector expanded by opening up new industries such as the textile and clothing industries which were agriculture based. After the revolution in 1952 led by Gamal Abd El Nasser, Egypt experienced a new phase of industrialization which was heavily financed by the state through direct government investments and other industries were established such as the steel, fertilizer, paper and mineral industries, yet the textile industry was still dominating the market (Gray, 1998). In 1974, the implementation of the Open Door Policy took place which moved away from the state-led development of Nasser's era to expand the local private sector and increase foreign investment. The main objective of the Open Door Policy led by Sadat's regime was to integrate the Egyptian economy into the global economy and to attract foreign investment to create new and more employment opportunities for Egypt's expanding labor force (Gray, 1998; Alissa, 2007). Starting 1985, Egypt evidenced an industrial liberalization phase which led to positive trend in industrial development. In 2004, another set of reforms took place led by the Prime Minister Ahmed Nazif and his team. These reforms concentrated on restructuring the financial sector, enhancing IT infrastructure, liberalizing trade and privatizing state led companies. These reforms stabilized to some extent the economy and 
stimulated growth. Also, the state undertook a policy of encouraging the export oriented industries and liberalizing imports to increase competition and integration with the global markets (Loewe, 2013).

Furthermore, the introduction of the new labor Law No. 12 of $2003^{11}$ deregulated the labor market in Egypt in face of the globalization era. Firstly, the Egyptian Authorities as in 2003 required the global firms to employ domestic labor and to offer them with the necessary training and education in order to provide the Egyptian labor force with job opportunities. Additionally, there is a better enforcement of labor laws to ensure that the global firms provide their employees with all the legal employment benefits such as social security benefits. Moreover, the global firms were required to employ 10 Egyptians for each foreigner. This has the effect that the growing labor force of Egypt is secured to be employed and to avoid the case that the Egyptian employees were laid off by the foreign firms. In this way, the Egyptian regulatory body made it harder for the global firms to exploit the underprivileged labor in Egypt by arranging more informal employment. Most importantly, the new labor Law of 2003 introduced flexible labor regulations with minimum government intervention. It has been concluded by Wahba and Assaad (2016) that the application of new labor law of 2003 reduced labor market rigidities and thus increased the probability of transitioning to formal employment from informal employment in Egypt.

The impact of these major reforms and trade agreements was to ease the environment of opening up business in Egypt and to liberalize trade in order to globalize the domestic economy and to encourage individuals to join the formal economy rather than the shadow economy.

Given the efforts to globalize the Egyptian economy and given the burden of the shadow economy on the formal economy, it is interesting to analyze the relationship between these two phenomena.

\footnotetext{
${ }^{11}$ For further details on the law, see http://www.egypt.gov.eg/english/laws/labour/ (Access: 24.03.2017)
} 


\section{Research design: data and methodology}

\subsection{Data description}

To examine the dynamic interconnections between economic globalization and the shadow economy in Egypt, we use the following variables: the KOF index of economic globalization (globalization), the size of government consumption (\% of GDP) (government spending), gross enrolment ratio at tertiary level (\%) (education), the share of value added of industry (\% of GDP) (industry), labor force participation, and the size of shadow economy (\% of GDP) (shadow). The source of data for KOF economic globalization index is Dreher (2006) and for the shadow economy is Hassan and Schneider (2016). All other data are from World Bank (2016) while labor force participation rate is from National Bank of Egypt yearly bulletin from 1976 to 2013. Dreher (2006) and Dreher et al (2008) follow Clark (2000), Norris (2000) and Keohane and Nye (2000) in defining the globalization. Globalization is defined as "the process of creating networks of connections among actors at multi-continental distances, mediated through a variety of flows including people, information and ideas, capital and goods." More detailed, the KOF economic globalization index takes into account the actual economic flows including trade, foreign direct investment, and portfolio investment. Trade considers the flow of imports and exports and portfolio investment considers the sum of a country's stock of assets and liabilities (all normalized by GDP). In addition, the index considers the trade and investment restrictions such as import barriers, mean tariff rates, taxes on international trade (as a share of current revenue) and an index of capital controls. The scale of index is from one (lowest degree of economic globalization) to 100 (the highest economic globalization). The data is from 1976 to 2013. The next important variable in our analysis is the relative size of shadow economy. Hassan and Schneider (2016) use the Multiple Indicators Multiple Causes (MIMIC) modelling approach to estimate the relative size for the shadow economy as percentage of GDP in Egypt. This confirmatory approach takes into account different indicators 
of the shadow economy instead of relying on only one proxy. It also considers a set of observable causes of the shadow economy such as taxes, regulation burden, the structure of domestic production and quality of institutions. We use annual data from 1976 to 2013 for our analysis. Tables A1 and A2 in Appendix A present the description and summary statistics of the variables in our analysis.

With reference to the above-mentioned theoretical discussions, we aim to address the following hypothesis:

Hypothesis: Shocks to positive changes in the economic globalization of Egypt lead to a negative and statistically significant response of the shadow economy in Egypt.

\subsection{Methodology}

We use the Vector autoregressive (VAR) model to estimate the interrelationships among our variables. The VAR provides a multivariate framework that relates changes in a particular variable to changes in its own lags and to changes in (the lags of) other variables:

$$
y_{t}=A_{1} y_{t-1}+\cdots+A_{p} y_{t-p}+B x_{t}+\varepsilon_{t}
$$

where $y_{t}$ is a vector of $\mathrm{k}$ endogenous variables, $x_{t}$ is a vector of $\mathrm{d}$ exogenous variables, $A_{1}, \ldots$, $A_{\mathrm{p}}$ and $B$ are matrices of coefficients to be estimated, and $\varepsilon_{t}$ is a vector of innovations that may be contemporaneously correlated but are uncorrelated both with their own lagged values and with all of the right-hand side variables (Dizaji et al., 2016).

Our vector of exogenous variable is defined as $x_{t}=$ [constant $]$. In the VAR model, all other variables are endogenous and affect each other with some specific lags. Thus, simultaneity is not an issue and the ordinary least squares (OLS) leads to consistent estimates.

We apply an unrestricted VAR model. The Phillips-Perron and ADF unit root tests indicate that all variables have a unit root and same order of integration (I(1)). The Johansen cointegeration test shows that there is long run relationship among I(1) variables. In this case, differencing will 
lead to the loss of long run useful information within our data. Sims (1980), Sims et al. (1990), and Doan (2000) have argued against differencing of cointegerated variables. Therefore, we use an unrestricted VAR model in levels of variables ${ }^{12}$. Various authors ${ }^{13}$ concluded that the unrestricted VAR models perform better in the short term than Vector Error Correction Models (VECM) in their simulations (Naka and Tufte, 1997). In our study, we are interested in impulse response functions (IRF) rather than the interpretation of each coefficient of the VAR model. We are using the impulse response functions (IRF) and Variance Decomposition Analysis (VDC) to examine the dynamic response of Egyptian shadow economy to positive shocks in economic globalization, while controlling for other factors. Using the IRF we can trace the magnitude of response to the shock over the years following initial shock as well as their statistical significance (Stock and Watson, 2001). Application of the VDC helps us to show the role and relative importance of a specific variable innovation in explaining the fluctuations of other variables in the VAR system.

\section{Results}

We use a VAR model with six variables to examine the impact of economic globalization changes in Egypt on the relative size of the shadow economy. In our unrestricted VAR model, the vector of endogenous variables is as follows:

$$
y_{t}=[\text { globalization, tertiary education, industry, government spending, }
$$

\section{labor force participation, shadow]}

This is our first choice as the Cholesky ordering in the VAR system. The first variable in a prespecified Cholesky ordering has an immediate effect on all other variables in the system, excluding the first variable and so on.

\footnotetext{
${ }^{12}$ See also Dizaji et al. (2016); Farzanegan and Markwardt (2009); Farzanegan (2011); Farzanegan and Raesian Parvari (2014) and Dizaji and Bergeijk (2013) for a similar approach.

${ }^{13}$ See also Engle and Yoo (1987) Clements and Hendry (1995) and Hoffman and Rasche (1996).
} 
We assume that economic globalization is a natural process which is followed by many countries and is not affected contemporaneously by other domestic factors in Egypt such as shadow economy, domestic production structure, labor market or education. In other words, the economic globalization in Egypt affect education participation, labor force participation, industrialization and informal economy contemporaneously and get affected by them with some lags. A number of studies in the field of comparative politics argues for exogeneity of economic globalization and treat international integration as an exogenous force imposed upon by local politics and economics. The increasing international normative pressure such as the belief in the "market logic" in constructing the liberalization process is playing an important role in making globalization inevitable (Fourcade-Gourinchas and Babb, 2002). The second variable in our ordering is tertiary education. Participation in the educational system is an accumulation of human capita which is influenced by an individual's motivation. Such motivation may be influenced by demand for human capital and skills following integration of an economy in international markets as a result of economic globalization. More incentives and investment in education improve the necessary stock of human capital for industrialization of an economy. Thus, industrial production is our third variable in ordering. Government spending is responsive to the economic liberalization and privatization. Removal of subsidies and freezing governmental job positions since 1990s in Egypt resulted to continuous decline in the share of government spending in economy. This latter and the previous variables shape the labor force participation rate in Egypt which is our forth variable in the model. We assume that the shadow economy is the most endogenous variable in the VAR system. The development of the shadow economy is a function of economic and institutional factors including the globalization trend. The Granger causality/block exogeneity Wald test (Enders, 2003, p. 284) is also supporting the mentioned ordering of variables (see Table B1 in Appendix B). This test detects whether the lags of one variable can Granger-cause other variables in the VAR system. The null hypothesis 
is that all lags of one variable can be excluded from each equation in the VAR system (see Farzanegan and Markwardt, 2009 for similar approach in ordering of variables). Changing in ordering of variables in the system may affect the impulse response results. Thus, for robustness check of our main results we use the generalized impulse responses (GIR) which are not sensible to a specific ordering of variables (Pesaran and Shin, 1998).

Another important step in estimating the VAR model is selection of an optimum lag length for variables. To find the optimum lag, we use information criteria such as LR, FPE (final prediction error), AIC (Akaike information criterion), SC (Schwarz information criterion), and HQ (Hannan-Quinn information criterion). We select a lag length of 2 on the basis of the LR, FPE, and AIC criteria and also with respect to stability and diagnostic tests. The VAR stability condition test (roots of characteristic polynomial) indicates that the VAR satisfies the stability condition (see Figure C1 in Appendix C). All roots have a modulus less than one and lie inside the unit circle, and the VAR model is stable (or stationary). Lack of auto-correlation in the estimated VAR model's residuals is also important for reliability of our results. Table C1 in Appendix $\mathrm{C}$ shows the results of the autocorrelation LM test. In sum, all diagnostic criteria show that our estimated VAR model as the basis for impulse response functions is stable and satisfactory.

\subsection{Impulse response functions}

In this study, the impulse response functions (IRF) trace out size, direction and duration of the simulated response of the shadow economy in Egypt to a one standard deviation shock in the economic globalization of Egypt. The middle line in IRFs displays the response of the shadow economy to a one standard deviation shock in the globalization variable. The statistical significance of simulated responses is also important. The dotted lines around simulated responses show confidence bands at 95\% confidence intervals, which are built using 1000 Monte Carlo simulations. The estimated responses are statistically different from zero if the 
error bands do not include the zero line. The vertical axis in the IRF shows the magnitude of responses and horizontal axis represents the years after initial shock.

Figure 3 shows that an increase in the economic globalization of Egypt has a statistically significant and negative impact on the size of the shadow economy in Egypt. The shadow economy reduction in the short term ( 2 years after the globalization shock) is statistically significant. To what extent the IRF in Figure 3 is sensible to the ordering of variables in the estimate VAR model? We estimate the Generalized IRF which does not depend on the VAR ordering. The result is identical to the illustrated IRF in Figure 3.

Figure 3. Impulse responses to a one standard deviation shock in economic globalization (at $95 \% \mathrm{CI})$

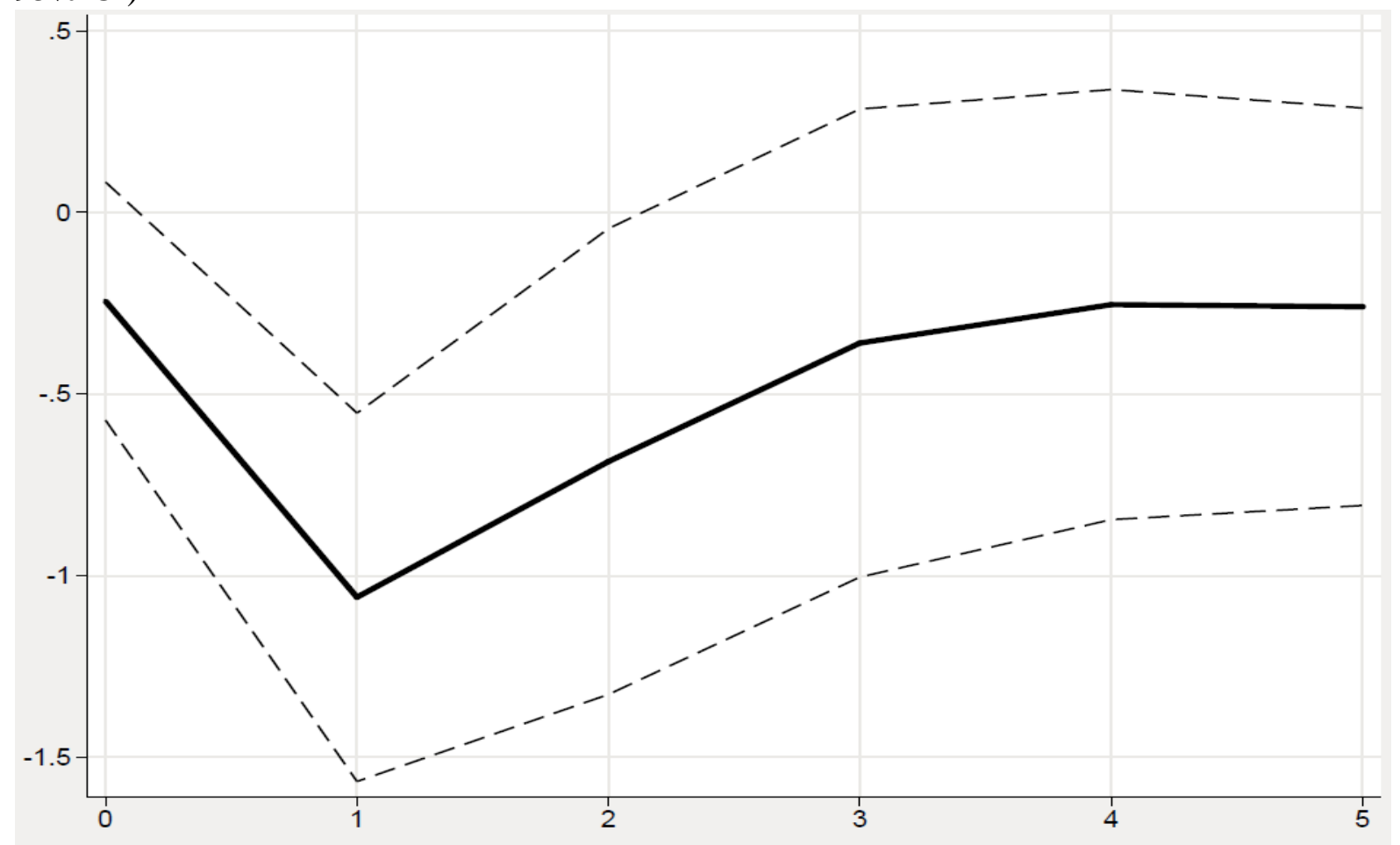

Note: The graphs show the impulse responses of shadow economy (as \% of GDP) to one-standard-deviation shock in the economic globalization index. The dotted lines represent \pm 2 standard deviation. The deviation from the baseline scenario of no shocks is on the vertical axis; the periods (years) after the shock are on the horizontal axis. The vertical axis shows the magnitude of the responses.

Furthermore, Sims and Zha (1999) suggest using one standard deviation for error bands in the IRFs. Figure 4 shows the above IRF by using $68 \%$ confidence interval. As expected, the 
negative response of the shadow economy and its duration does not change but the statistical significance of response is now evident until 3 years after initial shock.

Figure 4. Impulse responses to a one standard deviation shock in economic globalization (at $68 \% \mathrm{CI})$

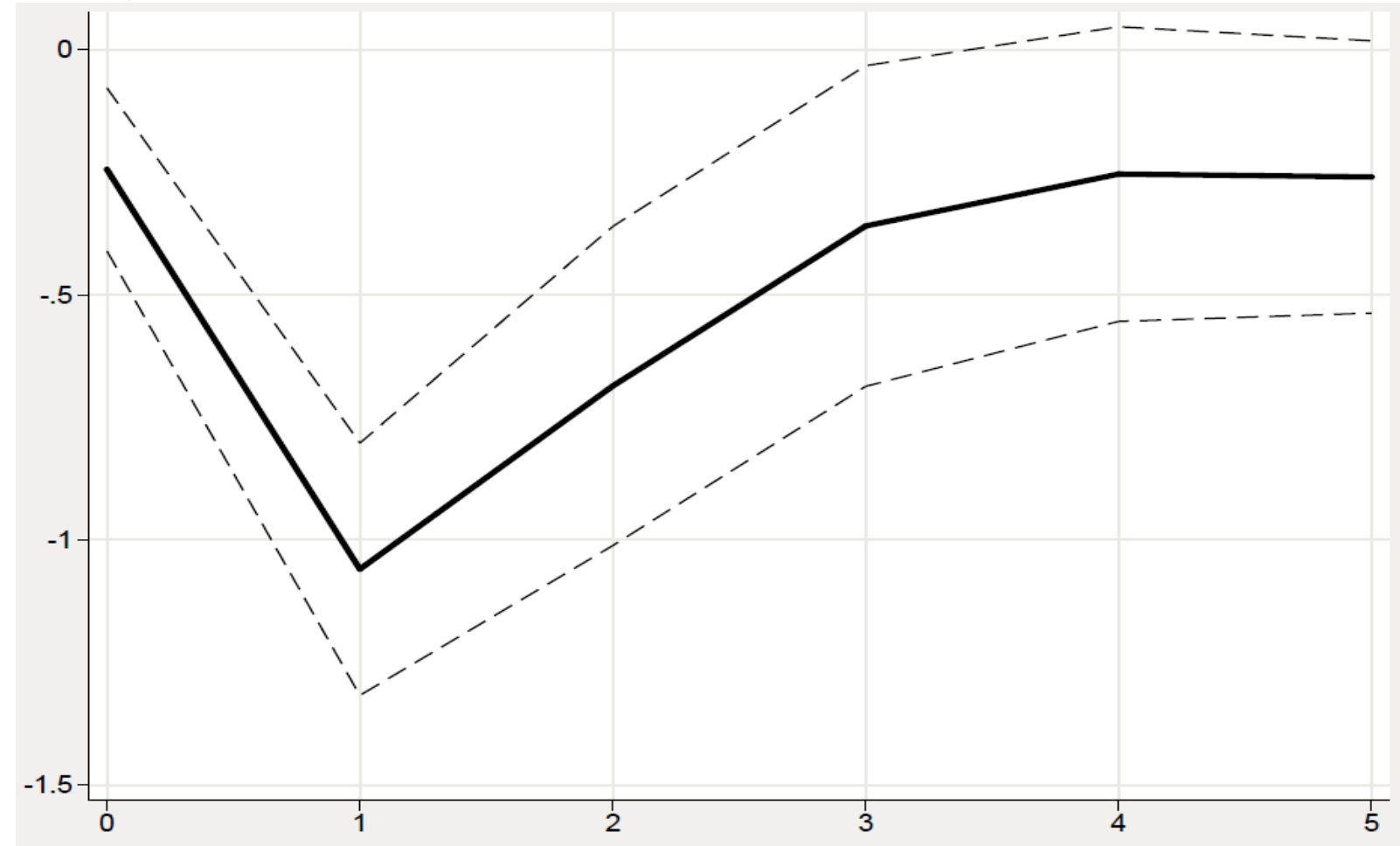

Note: The graphs show the impulse responses of shadow economy (as \% of GDP) to one-standard-deviation shock in the economic globalization index. The dotted lines represent \pm 1 standard deviation. The deviation from the baseline scenario of no shocks is on the vertical axis; the periods (years) after the shock are on the horizontal axis. The vertical axis shows the magnitude of the responses.

\subsection{Variance decomposition}

How much of the variance in the Egyptian shadow economy is explained by shocks in shadow economy itself, and how much is explained by shocks in globalization and other control variables? The variance decomposition (VDC) results in Table 1 show the variance of each variable from each source of shock. The first vertical column presents the number of years following a shock to which the decomposition applies, and the row numbers show the percentage of variance explained by the shock source. 
Table 1 shows that for almost all variables, the largest portion of variation is explained by their own fluctuations in the first year. Variance Decomposition of the shadow economy shows that the importance of economic globalization shocks in explaining the variation of the shadow economy is increasing significantly from $6 \%$ in the first year after shock to $44 \%$ within the first five years following shock, stabilizing its share around $40 \%$ in a decade after shock. Another relatively important source of shock in explaining the variance of the shadow economy in Egypt is the fluctuations in education. It explains $15 \%$ and $21 \%$ of variance of the shadow economy in the five and 10 years after the shock. The importance of government spending in variance of the shadow economy which was relatively higher in the first year after shock (11\%) reduces its significance in the forthcoming five and 10 years after shock. Economic globalization in Egypt, as evident in its variance decomposition, is to a large extent explained by its own changes of globalization trend. This supports the arguments for relatively exogenous nature of economic globalization in Egypt. The globalization ideology is pushing countries to integrate in international markets and adjust their local policies to facilitate such integration. The relative importance of economic globalization in explaining the shocks in education in the middle- and long- term can be also seen in Table 1. The same issue on the increasing role of globalization in explaining the variance of industrial production is shown in Table 1. Besides we can also refer to the relative increase in the importance of the shocks in shadow economy in explaining the variance of industrial production in Egypt over the five and 10 years after shock. The role of education and government spending shocks is also relatively important in explaining parts of fluctuations in labor force participation rate in Egypt. 
Table 1. Variance decomposition

\begin{tabular}{|c|c|c|c|c|c|c|}
\hline \multicolumn{7}{|c|}{ Variance Decomposition of economic globalization: } \\
\hline $\begin{array}{l}\text { Years after } \\
\text { shock }\end{array}$ & Globalization & Education & Industry & $\begin{array}{l}\text { Government } \\
\text { spending }\end{array}$ & $\begin{array}{l}\text { Labor force } \\
\text { participation }\end{array}$ & $\begin{array}{l}\text { Shadow } \\
\text { economy }\end{array}$ \\
\hline 1 & 100 & 0 & 0 & 0 & 0 & 0 \\
\hline 5 & 72 & 1 & 13 & 8 & 0 & 6 \\
\hline 10 & 58 & 5 & 12 & 8 & 11 & 6 \\
\hline \multicolumn{7}{|c|}{ Variance Decomposition of education: } \\
\hline $\begin{array}{ll}\text { Years } & \text { after } \\
\text { shock }\end{array}$ & Globalization & Education & Industry & $\begin{array}{l}\text { Government } \\
\text { spending }\end{array}$ & $\begin{array}{l}\text { Labor force } \\
\text { participation }\end{array}$ & $\begin{array}{l}\text { Shadow } \\
\text { economy }\end{array}$ \\
\hline 1 & 10 & 90 & 0 & 0 & 0 & 0 \\
\hline 5 & 22 & 66 & 3 & 0 & 9 & 1 \\
\hline 10 & 34 & 45 & 2 & 1 & 14 & 3 \\
\hline \multicolumn{7}{|c|}{ Variance Decomposition of industry: } \\
\hline $\begin{array}{l}\text { Years after } \\
\text { shock }\end{array}$ & Globalization & Education & Industry & $\begin{array}{l}\text { Government } \\
\text { spending }\end{array}$ & $\begin{array}{l}\text { Labor force } \\
\text { participation }\end{array}$ & $\begin{array}{l}\text { Shadow } \\
\text { economy }\end{array}$ \\
\hline 1 & 16 & 5 & 79 & 0 & 0 & 0 \\
\hline 5 & 22 & 6 & 46 & 1 & 10 & 15 \\
\hline 10 & 23 & 13 & 41 & 1 & 9 & 13 \\
\hline \multicolumn{7}{|c|}{ Variance Decomposition of government spending: } \\
\hline $\begin{array}{l}\text { Years after } \\
\text { shock }\end{array}$ & Globalization & Education & Industry & $\begin{array}{l}\text { Government } \\
\text { spending }\end{array}$ & $\begin{array}{l}\text { Labor force } \\
\text { participation }\end{array}$ & $\begin{array}{l}\text { Shadow } \\
\text { economy }\end{array}$ \\
\hline 1 & 1 & 3 & 0 & 95 & 0 & 0 \\
\hline 5 & 7 & 3 & 14 & 62 & 10 & 3 \\
\hline 10 & 10 & 2 & 10 & 41 & 31 & 4 \\
\hline \multicolumn{7}{|c|}{ Variance Decomposition of labor force participation: } \\
\hline $\begin{array}{l}\text { Years after } \\
\text { shock }\end{array}$ & Globalization & Education & Industry & $\begin{array}{l}\text { Government } \\
\text { spending }\end{array}$ & $\begin{array}{l}\text { Labor force } \\
\text { participation }\end{array}$ & $\begin{array}{l}\text { Shadow } \\
\text { economy }\end{array}$ \\
\hline 1 & 0 & 0 & 8 & 31 & 60 & 0 \\
\hline 5 & 1 & 17 & 6 & 17 & 57 & 3 \\
\hline 10 & 15 & 21 & 19 & 10 & 32 & 4 \\
\hline \multicolumn{7}{|c|}{ Variance Decomposition of shadow economy: } \\
\hline $\begin{array}{ll}\text { Years } & \text { after } \\
\text { shock } & \end{array}$ & Globalization & Education & $\begin{array}{l}\text { Industry } \\
\end{array}$ & $\begin{array}{l}\text { Government } \\
\text { spending }\end{array}$ & $\begin{array}{l}\text { Labor force } \\
\text { participation }\end{array}$ & $\begin{array}{l}\text { Shadow } \\
\text { economy }\end{array}$ \\
\hline 1 & 6 & 1 & 5 & 11 & 4 & 73 \\
\hline 5 & 44 & 15 & 3 & 5 & 9 & 24 \\
\hline 10 & 38 & 21 & 11 & 5 & 10 & 16 \\
\hline
\end{tabular}




\section{Conclusion}

We study how economic globalization in Egypt is affecting the development of the shadow economy. Addressing the shadow economy is one of the main concerns of policy makers. The agents in the shadow economy suffer from a series of deficiencies including lower productivity of labor and capital, lack of access to financial resources in the formal banking system, lack of resources to improve the technology of production, higher reliance on emission intensive inputs for their production (Biswas et al., 2012), lack of safety and environmental standards and tax evasion. The small informal businesses have low chances of achieving large scale of production and attached efficiencies of formal firms. They benefit from subsidized energies for their unregistered business, yet they do not contribute to the formal gross domestic production. However, informal firms may provide a safety net for the unemployed but informal employees are disadvantaged and suffer from a long term unstable career path, decreasing the incentive for accumulation of human capital and investment in education.

Economic globalization, by reducing the economic costs of doing business, imports and exports and investment, can expand productivity in the formal economy and available opportunities in the legal part of economy. A globalized economy can offer more promotion chances to upgrade the career path, motivating the informal agents to acquire skills required for formal economy which is boosting following a positive shock in economic integration of country.

To address the objective of this paper, we use time series data for the case of Egypt from 19762013. An unrestricted VAR model and its applied tools of IRF and VDA are applied to investigate the response of the shadow economy to positive shocks in economic globalization. Our IRF results show a statistically significant and negative response of the Egyptian shadow economy to a positive shock in Egyptian economic globalization. The negative response of shadow economy is at its lowest level within one year following shock. The negative response of shadow economy is statistically significant for the first 3 years following the shock. To 
conclude, the economic globalization is indeed will push formalization of Egyptian economy in short and middle term after the positive shock.

\section{References}

Acosta, P., Gasparini, L., 2007. Capital accumulation, trade liberalization, and rising wage inequality: The case of Argentina. Economic Development and Cultural Change 55, 793-812.

Alissa, S., 2007. The political economy of reform in Egypt: Understanding the role of institutions. Carnegie Endowment for International Peace 5, 1-32.

Aleman-Castilla, B., 2006. The effect of trade liberalization on informality and wages: Evidence from Mexico. CEP Discussion Paper No. 763. London School of Economics and Political Science.

Bacchetta, M., Ernst, S., Bustamante, J., 2009. Globalization and informal jobs in developing countries. International Labor Organization and World Trade Organization. Geneva, Switzerland. WTO Publications.

Biswas, A., Farzanegan, M.R., Thum, M., 2012. Pollution, shadow economy and corruption: Theory and evidence. Ecological Economics 75, 114-125.

Buehn, A., Farzanegan, M.R., 2012. Smuggling around the world: Evidence from structural equation modeling. Applied Economics 44, 3047-3064.

Buehn, A., Schneider, F., 2008. MIMIC models, cointegration and error correction: An application to the French shadow economy. Forschungsinstitut Zur Zukunft Der Arbeit Institute for the Study of Labor 33, 4-30.

Carr, M., Chen, M., 2002. Globalization and informal economy: How global trade and investment impact on the working poor. International Labor Office.

Chaudhry, I. S., Malik A., Faridi, M. Z., 2010. Exploring the causality relationship between trade liberalization, human capital and economic growth: Empirical evidence from Pakistan. Journal of Economics and International Finance 2, 175-182.

Clark, W. C., 2000. Environmental globalization, in governance in a globalizing world (Eds) J. S. Nye and J. D. Donahue, Brooking Institution Press, Washington, DC, 86-108.

Clements, M. P., Hendry, D.F., 1995. Forecasting in cointegrated systems. Journal of Applied Econometrics 10, 127-146.

Dizaji, S. F, Bergeijk, P. AG. van (2013). Potential early phase success and ultimate failure of economic sanctions: A VAR approach with an application to Iran. Journal of Peace Research 50, 721-736.

Dizaji, S.F., Farzanegan, M.R., Naghavi, A. 2016. Political institutions and government spending behavior: Theory and evidence from Iran. International Tax and Public Finance 23, 522-549.

Doan, T., 2000. RATS version 5 User's Guide. Estima, Evanston. 
Dong, B., Dulleck, N., Torgler, B., 2012. Conditional corruption. Journal of Economic Psychology 33, 609-627.

Dreher, A., 2006. Does Globalization affect growth? Evidence from a new index of globalization, Applied Economics 38, 1091-1110.

Dreher, A., Gaston, N., Martens, P., 2008. Measuring globalization. Gauging its consequences. Springer New York.

Dreher A., Kotsogiannis, C., Martens, P., 2009. How do institutions affect corruption and the shadow economy? International Tax and Public Finance 16, 773-796.

Egharevba, M., 2011. Labor market and the poverty of globalization in the Nigerian informal economy. MINILS Publications. Ilorin, Nigeria.

Enders, W. 2003. Applied Econometric Time Series. Hoboken, NJ: Wiley.

Engle, R. F, Yoo, B. S. (1987). Forecasting and testing in co-integrated systems. Journal of Econometrics 35, 143-159.

Farzanegan, M.R., 2011. Oil revenues shocks and government spending behavior in Iran. Energy Economics 33, 1055-1069.

Farzanegan, M.R., Markwardt, G., 2009. The effects of oil price shocks on the Iranian economy. Energy Economics 31, 134-151.

Farzanegan, M.R, Raeisian Parvari, M., 2014. Iranian-Oil-Free zone and international oil prices. Energy Economics 45, 364-372.

Fourcade-Gourinchas, M., Babb, S., 2002. The rebirth of the liberal creed: Paths to neoliberalism in four countries. American Journal of Sociology 108, 533-79.

Geronazzo, S., 2016. Increased trade openness, productivity, employment and wages: A difference-in-differences approach. Estudios Regionales en Economía, Población y Desarrollo. Cuadernos de Trabajo de la UACJ, Universidad Autónoma de Ciudad Juárez 32, 3-41.

Gerxhani, K,. 2004. The informal sector in developed and less developed countries: A literature review. Public Choice 120, 267-300.

Goldberg, P., Pavcnik, N., 2003. The response of informal sector to trade liberalization. Journal of Development Economics 72, 463-496.

Gray, M., 1998. Economic reform, privatization and tourism in Egypt. Middle Eastern Studies $34,91-112$.

Herath, H. S. M. P., 2010. Impact of trade liberalization on economic growth of Sri Lanka: An econometric investigation. In: Proceedings of the 1st International Conference on Business and Information, University of Kelaniya.

Hassan, M., Schneider, F., 2016. Modelling the shadow economy in Egypt; A CDA and MIMIC approach. Journal of Economics and Political Economy 3, 309-339.

Hoffman, D. L., Rasche, R.H., 1996. Assessing forecast performance in a cointegrated system. Journal of Applied Econometrics 11, 495-517. 
Johnson, S., Kauffman, D., Zoido-Lobaton, P., 1998. Regulatory discretion and the unofficial economy. American Economic Review Papers and Proceedings 88, 387-393.

Kearney, A. T., 2006. The globalization index. Foreign Policy, Carnegie Endowment for International Peace, 74-81.

Keohane, R. O., Nye, J. S., 2000. Introduction, in governance in a globalizing World (Eds) J. S. Nye and J. D. Donahue, Brookings Institution Press, Washington, DC, 1-44.

La Porta, R., Shleifer, A., 2014. Informality and development. Journal of Economic Perspectives 28, 109-126.

Loewe, M., 2013. Industrial policy in Egypt 2004-2011. German Development Institute. Discussion Paper No. 13/2013.

Melitz, M. J., 2003. The impact of trade on intra-industry reallocations and aggregate industry productivity. Econometrica 71, 1695-1725.

Naka, A., Tufte, D., 1997. Examining impulse response functions in cointegrated systems. Applied Economics 29, 1593-1603.

National Bank of Egypt. Yearly Economic Bulletin 1976-2013. Available at: http://www.nbe.com.eg/en/malia/Economic_Bulletin.aspx

Norris, P., 2000, Global governance and cosmopolitan Citizens, in: Joseph S. Nye and John D. Donahue (eds.), Governance in a Globalizing World, Brookings Institution Press, Washington, D.C., 155-177.

Pesaran, M. H., Shin, Y. (1998). Generalized impulse response analysis in linear multivariate models. Economics Letters 58, 17-29.

Pham, H., 2011. Globalisation versus informality: Evidence from developing countries. Working Paper No. 74. Forum Internationale Wissenschaft.

Potrafke, N., 2014. The evidence on globalization. The World Economy 38, 509-552.

Razmi, M. J., Falahi, M. A., Montazeri, S., 2013. Institutional quality and underground economy of 51 OIC member countries. Universal Journal of Management and Social Sciences 3, 1-14.

Schneider, F., 2010. The influence of public institutions on the shadow economy: An empirical investigation for OECD countries. Review of Law and Economics 6, 113-140.

Schneider, F., Buehn, A., Montenegro, C. E., 2010. New estimates for the shadow economies all over the world, International Economic Journal 24, 443- 461.

Schneider, F. Enste, D.H., 2000. Shadow economies: size, causes and consequences. Journal of Economic Literature 38, 77-114.

Schneider, F., 2005. Shadow economies around the world: What do we really know? European Journal of Political Economy 21, 598-642.

Selwaness, I., Zaki, C., 2013. Assessing the impact of trade reforms on informality in Egypt. Working Paper No. 759, Economic Research Forum, Cairo, Egypt. 
Siggel, E., 2010. The Indian informal sector: The impact of globalization and reform. International Labour Review 149, 93-105.

Sims, C. A., 1980. Macroeconomics and reality. Econometrica 48, 1-48.

Sims, C.A., Zha, T. (1999). Error bands for impulse responses. Econometrica 67, 11131156.

Sims, C. A., Stock, J. H., Watson, M.W., 1990. Inference in linear time series models with some unit roots. Econometrica 58, 113-44.

Stock, J. H., Watson, M., 2001. Vector autoregressions. Journal of Economic Perspectives $15,101-115$.

Temkin, B., Veizaga, J., 2010. The impact of economic globalization on labor informality. New Global Studies 4, 1-31.

Utkulu, U., Özdemir, D., 2004. Does trade liberalization cause a long run Economic Growth in Turkey. Economic Change and Restructuring 37, 245-266.

Verick, S., 2008. The impact of globalization on the informal sector in Africa. Economic and Social Policy Division, UNECA, Addis Ababa.

Wahba, J., Assaad, R., 2016. Flexible labor regulations and informality in Egypt. Review of Development Economics, 1-18. DOI: 10.1111/rode.12288

World Bank, 2016. World Development Indicators. World Bank. Available at: http://databank.worldbank.org/data/reports.aspx?source=world-developmentindicators 


\section{Appendix A}

Table A1. Variables

\begin{tabular}{|c|c|c|}
\hline Variables & Definition & Source \\
\hline $\begin{array}{c}\text { Economic } \\
\text { globalization index }\end{array}$ & $\begin{array}{l}\text { Economic globalization has two } \\
\text { dimensions. First, actual economic } \\
\text { flows. Second, proxies for restrictions } \\
\text { to trade and capital. }\end{array}$ & $\begin{array}{c}\text { Dreher et al. } 2008 \text { and } \\
\text { KOF: } \\
\text { http://globalization.kof.ethz.ch/ }\end{array}$ \\
\hline Industry & $\begin{array}{l}\text { It comprises value added in mining, } \\
\text { manufacturing construction, } \\
\text { electricity, water, and Gas. Value } \\
\text { added is the net output of a sector after } \\
\text { adding up all outputs and subtracting } \\
\text { intermediate inputs. }\end{array}$ & World Bank (2016) \\
\hline $\begin{array}{l}\text { Government } \\
\text { spending }\end{array}$ & $\begin{array}{l}\text { General government final } \\
\text { consumption expenditure includes all } \\
\text { government current expenditures for } \\
\text { purchases of goods and services } \\
\text { (including compensation of } \\
\text { employees). It also includes most } \\
\text { expenditures on national defense and } \\
\text { security, but excludes government } \\
\text { military expenditures that are part of } \\
\text { government capital formation }\end{array}$ & World Bank (2016) \\
\hline Education & $\begin{array}{l}\text { Tertiary school enrollment ratio is the } \\
\text { ratio of total enrollment, regardless of } \\
\text { age, to the population of the age group } \\
\text { that officially corresponds to the level } \\
\text { of education shown. }\end{array}$ & World Bank (2016) \\
\hline $\begin{array}{c}\text { Labor force } \\
\text { participation rate }\end{array}$ & $\begin{array}{l}\text { Labor force participation rate for ages } \\
15-24 \text { is the proportion of the } \\
\text { population that is economically active }\end{array}$ & $\begin{array}{c}\text { National Bank of Egypt - Yearly } \\
\text { Economic Bulletin }\end{array}$ \\
\hline Shadow economy & $\begin{array}{l}\text { All economic activities that should } \\
\text { have included in the national GDP. It } \\
\text { excludes Do-it-Yourself, criminal and } \\
\text { voluntary activities. Size of the } \\
\text { shadow economy is measured as } \% \text { of } \\
\text { GDP by MIMIC model. }\end{array}$ & Hassan and Schneider (2016) \\
\hline
\end{tabular}


Table A2. Summary Statistics

\begin{tabular}{|l|l|l|l|l|l|}
\hline Variable & Obs. & Mean & Std. Dev. & Min & Max \\
\hline Shadow & 38 & 28.00 & 5.07 & 17.94 & 36.36 \\
\hline Globalization & 38 & 39.12 & 6.33 & 28.66 & 50.27 \\
\hline Industry & 38 & 33.03 & 3.93 & 26.20 & 38.89 \\
\hline $\begin{array}{l}\text { Government } \\
\text { spending }\end{array}$ & 38 & 13.62 & 3.53 & 10.29 & 24.83 \\
\hline Inflation & 38 & 10.86 & 6.01 & 0.87 & 31.14 \\
\hline $\begin{array}{l}\text { Labor force } \\
\text { participation }\end{array}$ & 38 & 28.16 & 3.39 & 22.56 & 33.66 \\
\hline Female education & 38 & 18.01 & 7.54 & 8.60 & 29.52 \\
\hline Male education & 38 & 26.04 & 4.97 & 15.89 & 33.60 \\
\hline Tertiary education & 38 & 44.05 & 12.16 & 25.15 & 61.74 \\
\hline
\end{tabular}




\section{Appendix B}

\section{Table B1. VAR Granger Causality/Block Exogeneity Wald Tests}

VAR Granger Causality/Block Exogeneity Wald Tests

Sample: 19762013

Included observations: 36

\begin{tabular}{cccc}
\hline \hline Dependent variable: Globalization & & & \\
\hline \hline Excluded & Chi-sq & Degree of freedom (df) & Probability (Prob.) \\
\hline \hline Education & 0.473947 & 2 & 0.7890 \\
Industry & 3.968879 & 2 & 0.1375 \\
Government spending & 3.472281 & 2 & 0.1762 \\
Labor force participation & 0.737771 & 2 & 0.6915 \\
shadow & 0.313541 & 10 & 0.8549 \\
\hline \hline All & 13.58738 & \multirow{2}{*}{0.1927} \\
\hline
\end{tabular}

Dependent variable: Education

\begin{tabular}{cccc}
\hline \hline Excluded & Chi-sq & df & Prob. \\
\hline \hline globalization & 3.624213 & 2 & 0.1633 \\
industry & 0.341552 & 2 & 0.8430 \\
Government spending & 1.071947 & 2 & 0.5851 \\
Labor force participation & 1.202913 & 2 & 0.5480 \\
Shadow & 0.281076 & 2 & 0.8689 \\
\hline \hline All & 11.81213 & 10 & 0.2978 \\
\hline \hline Dependent variable: Industry & & & Prob. \\
\hline \hline Excluded & Chi-sq & df & 0.4052 \\
Globalization & 1.806715 & 2 & 0.6430 \\
Education & 0.883120 & 2 & 0.7890 \\
Government spending & 0.473965 & 2 & 0.1042 \\
Labor force participation & 4.522493 & 2 & 0.0133 \\
shadow & 8.634558 & 2 & 0.1875 \\
\hline \hline
\end{tabular}

Dependent variable: Government spending

\begin{tabular}{cccc}
\hline \hline Excluded & Chi-sq & df & Prob. \\
\hline \hline Globalization & 2.931302 & 2 & 0.2309 \\
Education & 2.728230 & 2 & 0.2556 \\
Industry & 7.839558 & 2 & 0.0198 \\
Labor force participation & 0.189388 & 2 & 0.9097 \\
shadow & 1.788081 & 2 & 0.4090 \\
\hline \hline All & 23.75110 & 10 & 0.0083 \\
\hline \hline
\end{tabular}

Dependent variable: Labor force participation

\begin{tabular}{cccc}
\hline \hline Excluded & Chi-sq & df & Prob. \\
\hline \hline globalization & 0.614736 & 2 & 0.7354
\end{tabular}




\begin{tabular}{cccc} 
Education & 6.240607 & 2 & 0.0441 \\
Industry & 5.357689 & 2 & 0.0686 \\
Government spending & 1.403552 & 2 & 0.4957 \\
Shadow & 10.47626 & 2 & 0.0053 \\
\hline \hline All & 31.32990 & 10 & 0.0005 \\
\hline \hline Dependent variable: Shadow & & & Prob. \\
\hline \hline Excluded & Chi-sq & df & 0.0026 \\
Globalization & 11.86679 & 2 & 0.0321 \\
Education & 6.875795 & 2 & 0.1288 \\
Industry & 4.099343 & 2 & 0.0032 \\
Government spending & 11.47300 & 2 & 0.0072 \\
Labor force participation & 9.862555 & 2 & 0.0000 \\
\hline \hline All & 39.87442 & 10 & \\
\hline \hline
\end{tabular}




\section{Appendix C}

\section{Figure C1. Stability condition test}

Inverse Roots of AR Characteristic Polynomial

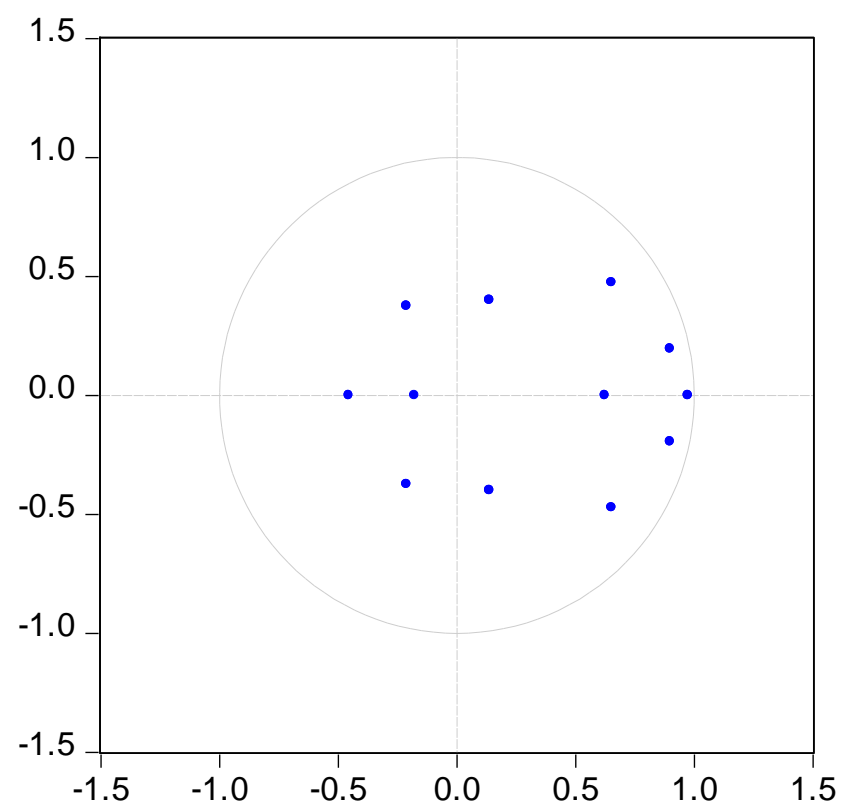

Table C1. Serial correlation LM test

VAR Residual Serial Correlation LM Tests

Null Hypothesis: no serial correlation at lag order $\mathrm{h}$

Sample: 19762013

Included observations: 36

\begin{tabular}{ccc}
\hline \hline Lags & LM-Stat & Prob. \\
\hline \hline 1 & 41.18842 & 0.2540 \\
2 & 41.67688 & 0.2375 \\
3 & 32.58830 & 0.6316 \\
\hline \hline
\end{tabular}

Probs. from chi-square with $36 \mathrm{df}$. 